\title{
Effect of Cooking and Packaging Methods on the Thiobarbituric Acid Reactive Substances and Cholesterol Oxidation Products of Turkey Thigh Meat Patties During Storage
}

\author{
S. J. Hur*, S. T. Joo*, G. B. Park*, I. S. Kim** and S. K. Jin**
}

Division of Animal Science, College of Agriculture, Gyeongsang National University, Jinju 660-701, Korea* Department of Animal Resources Technology, Jinju National University, Jinju 660-758, Korea**

$$
\begin{gathered}
\text { 가열방법과 포장조건이 칠면조육 패티의 저장중 } \\
\text { 지방산화와 콜레스테롤 산화물에 미치는 효과 } \\
\text { 허선진* . 주선태*. 박구부*. 김일석** . 진상근** } \\
\text { 경상대학교 동물자원과학부*, 진주산업대학교 동물소재공학과** }
\end{gathered}
$$

적 요

가열방법과 포장방법이 저장기간 동안 칠면조육 패티의 지방산화(TBARS)와 콜레스테롤 산화물 함량에 미치는 효과를 조사하기 위하여, 칠면조 다리육을 분쇄하여 패티를 제조하였다. 칠면조육 패티는 5 가지 가 열방법(oven cooking, pan frying, deep frying, boiling, microwaving)으로 가열한 후 각각 함기포장과 진공포장 한 후 저장하면서 시험에 공시하였다. 지방산패도는 함기포장과 진공포장 모두 저장초기에는 boiling 방법 이 유의적으로 $(\mathrm{P}<0.05)$ 높게 나타났으나, 저장 말기에는 microwaving 방법이 가장 높은 지방산패도를 나타 내었다(P<0.05). 또한 oven cooking 방법은 전 저장기간동안 함기포장과 진공포장 모두에서 가장 낮은 지방 산 패도값을 나타내었다 $(\mathrm{P}<0.05)$. 총 콜레스테롤 산화물의 량은 전 저장기간동안 boiling 방법이 가장 낮은 함량을 나타내었고 $(\mathrm{P}<0.05)$, microwaving 방법이 가장 높은 함량을 나타내었다 $(\mathrm{P}<0.05)$. 각각의 콜레스테롤 산화물의 함량을 보면, 7a-hydroxycholesterol은 pan frying 방법이 가장 낮은 함량을 나타내었고( $\mathrm{P}<0.05)$, microwaving 방법이 가장 높은 함량을 나타내었다 $(\mathrm{P}<0.05)$. a-epoxide의 량은 boiling 방법이 가장 낮은 함량 을 나타내었으며, pan frying 방법에서 가장 높게 나타났다 $(\mathrm{P}<0.05)$. $\beta$-epoxide 함량은 pan frying 방법이 가 장 낮은 함량을 나타내었으며 $(\mathrm{P}<0.05)$, deep frying 방법과 microwaving 방법에서 가장 높은 함량을 나타내 었다 $(\mathrm{P}<0.05)$. 또한 7-ketocholesterol의 함량은 microwaving 방법에서 가장 높게 나타났다 $(\mathrm{P}<0.05)$.

(주요어 : Turkey, TBARS, Cholesterol oxidation products, Cooking method, Packaging methods)

\section{INTRODUCTION}

Meat is a complex food with a highly structured nutritional composition and major source of cholesterol in the diet. It becomes edible and more digestible when it is subjected to cooking. However, heat treatment can lead to undesirable modifications, such as the loss of the nutritional value of meats mainly due to lipid oxidation and changes in some components of the cholesterol. The degree of oxide formation is related to processing temperature, heating time, storage conditions, level of activator present, packaging and most of the oxides found in foods were subjected to processing conditions or exposure to heat(Paniangvait et al., 1995). cholesterol oxidation products(COPs) have been known to be more injurious to arterial cells than pure

Corresponding author : S. K. Jin, Department of Animal Resources Technology, Jinju National University. 660758 Jinju, Korea, Tel : 055-751-3283, Fax : 055-751-3514, E-mail : skjin@jinju.ac.kr 
cholesterol and are more directly connected to the development of atherosclerosis and coronary heart disease(Addis, 1986). COPs deteriorated the bioavailability of cholesterol by inhibiting cholesterol biosynthesis(Lund and Bjorkhem, 1994) and dietary uptake of cholesterol(Peng et al., 1985). COPs also impaired a membrane function, which results in altered membrane permeability(Hennig and Boissonneault, 1987). On the other hand, natural cholesterol had no atherogenic or hypercholesterolemic effect and had a much lower influence on the activities of most enzymes than COPs(Smith, 1987). The most predominant oxidized cholesterol detected was 7-ketocholesterol, as well as $\beta$-epoxycholesterol and a -epoxycholesterol. Many studies demonstrated that the amount of COPs in foods could frequently reach $1 \%$ of total cholesterol and occasionally $10 \%$ or more (Addis, 1986). The lipid oxidation has been associated with quality deterioration caused by the development of off-flavors and off-odors during storage(Kumar and Singhal, 1992). More recently, interest in the possible toxicological effects of lipid oxidation products, particularly COPs has increased. These researches are important for human health and meat quality. Turkey is major animal in poultry industry. However, turkey is not much consuming in our meat markets, and no study was conducted on the turkey. The object of this study is to investigate the effects of cooking and packaging methods on the TBARS and cholesterol oxidation products of turkey thigh meat patties.

\section{П MATERIALS AND METHODS}

\section{Sample preparation}

The White Holland turkey thigh meats with skin were ground twice through a 3-mm plate and patties were prepared without additives. Patties(contain 15\% fat) were approximately $9 \mathrm{~cm}$ in diameter, $1.5 \mathrm{~cm}$ in thickness and weight $100 \mathrm{~g}$. Patties were cooked using 5 different methods (oven cooking, pan frying, oil deep frying, boiling, and microwaving) to an internal temperature of $85 \sim)^{\circ} \mathrm{C}$ (internal temperature checked by internal thermometer).

1) Oven cooking. The patties were placed in an electric oven and cooked. The electric oven utilized a heating bar heat to cook the top and bottom surfaces as each patty turned over twice.

2) Pan frying. The patties were placed on the electric pan and cooked. Each patty was turned over twice.

3) Oil deep frying. The patties were submerged into the hot corn oill $\left(160 \sim 30^{\circ} \mathrm{C}\right.$ and cooked.

4) Boiling. The patties were put into the zipperbag and boiled $\left(100^{\circ} \mathrm{C}\right.$ Omin) in a water bath(Fisher 120V 50/60Hz, Springfield, USA)

5) Microwave. The patties were placed in a glass dish and cooked(the patty was turned over twice between cycles) in a microwave oven(General Electric JE 1590WC, 2450MHz, Louisville, USA).

Five cooking treatment samples were vacuum packaged in a high oxygen impermeable PVDC bag $\left(9.3 \mathrm{~m} \ell \mathrm{O}_{2} / \mathrm{m}^{2} / 24 \mathrm{~h}\right.$ at $0^{\circ} \mathrm{C}$ Koch, Kansas City, USA) and stored at $4^{\circ} \mathrm{C}$ luring 0,1 , and 2weeks and also aerobic packaged in oxygen permeable PVC zipperbags(polyethylene, Associated Bag Company, Milwaukee, USA) and stored at $4{ }^{\circ} \mathrm{C}$ during 0.3 , and 7 days.

\section{Lipid oxidation(TBARS)}

Lipid oxidation was determined by the modified TBARS method of Buege and Aust(1978). Five grams of meat were weighted into a $50 \mathrm{~m} \ell$ test tube and homogenized with $15 \mathrm{~m} \ell$ of deionized distilled water(DDW) using a polytron homogenizer(Type PT 10/35, Brinkman Instruments Inc., Westbury, NY) for $10 \mathrm{~s}$ at the highest speed. 
One m $\ell$ of meat homogenate was transferred into a disposable test tube $(3 \times 100 \mathrm{~mm})$ and butylated hydroxyanisole(50ul, 7.2\%) and thiobarbituric acid/trichloroacetic acid(TBA/TCA; $2 \mathrm{~m} \ell$ ) were added. The mixture was vortexed and then incubated in a boiling water bath for $15 \mathrm{~min}$ to develop color. Then the sample was cooled in cold water for $10 \mathrm{~min}$, vortexed again, and centrifuged for $15 \mathrm{~min}$ at $2000 \mathrm{~g}$. The absorbance of the resulting supernatant solution was determined at 531nm against a blank containing $1 \mathrm{~m} \ell$ of DDW and $2 \mathrm{~m} \ell$ of TBA/TCA solution. The amounts of TBARS were expressed as milligrams of malondialdehyde per kilogram of meat.

\section{Cholesterol oxidation products(COPs)}

The COPs in samples were determined by the method described by Ahn et al(1999). The dried lipid by method of Folch et al(1957) were dissolved with an aliquot of hexane to make $0.1 \mathrm{~g}$ fat $/ \mathrm{m} \ell$ hexane and used for the next step. Silicic acid(100mesh), celite-545, and $\mathrm{CaHPO}_{4}$ (10:9:1, $\mathrm{w} / \mathrm{w} / \mathrm{w}$ ) mixture in chloroform was prepared and packed into a glass column. The columns were washed with $10 \mathrm{~m} \ell$ of hexane: ethyl acetate(9:1 $\mathrm{v} / \mathrm{v}$, solvent 1) before loading sample. Lipid sample(0.2g) dissolved in hexane were added with an internal standard(5-a-cholestane) and loaded onto the silicic acid column. Neutral lipids, cholesterol, and phospholipid were eluted by passing hexane: ethyl acetate( $9: 1, \mathrm{v} / \mathrm{v})$ and hexane: ethyl acetate: diethyl ether(4:1:2, v/v/v) through the column. Then cholesterol oxides were eluted with acetone: ethyl acetate: methanol (10:10:1) and dried under nitrogen. The dried cholesterol oxides were added with 200ul pyridine and 100ul BSTFA $+1 \%$ TMCS and derivartized by heating in a dry bath $\left(80^{\circ} \mathrm{C}\right.$ for $1 \mathrm{hr}$ and analyzed using a GC(Hewlett Packard 6890) equipped with an on-column capillary injector and a flame ionization detector(FID). A ramped oven temperature condition $\left(180^{\circ} \mathrm{C}\right.$ or 2.5 min, increased to $230^{\circ} \mathrm{C}$ it $2.5^{\circ} \mathrm{C}$ in, then held at $230^{\circ} \mathrm{C}$ or $7.5 \mathrm{~min}$ ) was used. Temperatures of both the inlet and detector were $280^{\circ} \mathrm{C}$ Helium was the carrier gas with linear flow at $1.1 \mathrm{~m} \ell / \mathrm{min}$. Detector(FID) air, $\mathrm{H}_{2}$, and make-up gas(He) flows were 350, 35, and $43 \mathrm{~m} \ell / \mathrm{min}$, respectively. Fatty acids were identified by comparison of retention times of known standards. Relative quantities were expressed as weight percent of total fatty acids.

\section{Statistical analysis}

Data were analyzed using the generalized linear model procedure of SAS software(1996) StudentNewman-Keuls multiple range test. Significance was defined at $\mathrm{P}<0.05$.

\section{RESULTS AND DISCUSSION}

\section{TBARS values}

Effects of cooking and packaging methods on the TBARS are shown in Table 1. A significant increase $(\mathrm{P}<0.05)$ in the TBARS values of all cooked samples by storage, which is in agreement with the finding of Kesava et al(1996). It is well known that, even during storage periods after heating, lipid oxidation does occur. At the 0 day of storage, both aerobically packaged and vacuum packaged TBARS value was no significant. In contrast, the levels of TBARS significantly $(\mathrm{P}<$ 0.05 ) increased with storage periods and vacuum packaged thigh meat produced less TBARS than the aerobically packaged samples. At the beginning of storage, aerobically packaged meat cooked by boiling method produced significantly $(\mathrm{P}<$ 0.05) higher TBARS than that of others. However, the TBARS of microwaved meat with vacuum packaging significantly $(\mathrm{P}<0.05)$ increased rapidly after 1 week of storage and also aerobically packaging significantly $(\mathrm{P}<0.05)$ increased although 
Table 1. Effect of cooking and packaging methods on the thiobarbituric acid reactive substances of turkey thigh meat patties during storage

\begin{tabular}{|c|c|c|c|c|c|c|c|c|}
\hline \multirow{3}{*}{ Treatments } & \multicolumn{8}{|c|}{ Storage period(days) } \\
\hline & \multicolumn{4}{|c|}{ Aerobic packaging } & \multicolumn{4}{|c|}{ Vacuum packaging } \\
\hline & 0 & 3 & 7 & SEM & 0 & 7 & 14 & SEM \\
\hline & ........... & $\cdots \cdots \cdots$ & 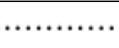 & $\mathrm{MA}^{1)} \mathrm{n}$ & g meat & (n........ & f......... & .......... \\
\hline Oven cooking & $3.29^{\mathrm{Cc}}$ & $14.28^{\mathrm{Db}}$ & $14.79^{\mathrm{Da}}$ & 0.062 & $3.24^{\mathrm{Cc}}$ & $4.43^{\mathrm{Cb}}$ & $4.95^{\mathrm{Da}}$ & 0.050 \\
\hline Pan frying & $3.94^{\mathrm{Bb}}$ & $14.89^{\mathrm{Ca}}$ & $15.18^{\mathrm{Ca}}$ & 0.113 & $4.02^{\mathrm{Bb}}$ & $4.48^{\mathrm{Ca}}$ & $5.02^{\mathrm{Da}}$ & 0.076 \\
\hline Deep frying & $4.14^{\mathrm{Bc}}$ & $15.07^{\mathrm{Cb}}$ & $15.36^{\mathrm{Ca}}$ & 0.068 & $4.14^{\mathrm{Bc}}$ & $4.92^{\mathrm{Cb}}$ & $5.28^{\mathrm{Ca}}$ & 0.101 \\
\hline Boiling & $4.52^{\mathrm{Ac}}$ & $16.72^{\mathrm{Bb}}$ & $17.55^{\mathrm{Ba}}$ & 0.088 & $4.65^{\mathrm{Ac}}$ & $5.29^{\mathrm{Bb}}$ & $5.59^{\mathrm{Ba}}$ & 0.051 \\
\hline Microwaving & $4.20^{\mathrm{Bc}}$ & $17.54^{\mathrm{Ab}}$ & $18.59^{\text {Аа }}$ & 0.102 & $4.29^{\mathrm{Bb}}$ & $5.95^{\mathrm{Aa}}$ & $6.06^{\text {Aa }}$ & 0.050 \\
\hline SEM & 0.086 & 0.080 & 0.099 & - & 0.062 & 0.072 & 0.072 & - \\
\hline
\end{tabular}

a,b,c Different letters within a row are significantly different $(\mathrm{P}<0.05)$.

A,B,C,D Different letters within a column are significantly different $(\mathrm{P}<0.05)$.

1) MA : Malonaldehyde.

storage period was 3 days. At the end of storage, micrewaved sample was the highest and oven cooked sample was the lowest than the other samples in both aerobically and vacuum packaging samples. Paniangvait et al(1995) reported that the degree of oxide formation is related to processing temperature, length of heating time, storage conditions, level of activator present and packaging. Most of the oxides found were in foods are subjected to processing conditions or exposure to heat(Paniangvait et al., 1995). Monahan et al(1992) found that lipid oxidation in raw samples was low compared to processed samples and may account for the low rates of cholesterol oxidation. The rate and the extent of lipid oxidation are dependent on several factors, the most important being the level of polyunsaturated fatty acids present(Allen and Foegeding, 1981). Apte and Morrissey(1987) clearly showed that the ferritin fraction contributed significantly to lipid oxidation in heated meat systems. In present study, we found that the cooking methods and packaging methods influenced the levels of lipid oxidation and the increased lipid oxidation is probably related to membrane damage. Especially, microwaving produced higher level of TBARS than those of other because the microwaving method should be easily infiltration into meat core. Thus, we assumed that easy and quick cooking method should be inducing the lipid oxidation easily and quickly.

\section{Total cholesterol oxidation products}

The amounts of total COPs by cooking methods and packaging methods shown in Table 2. The amount of total COPs in cooked thigh meat increased with storage and the increase was linear with storage time. Due to the presence of one double bond, cholesterol is susceptible to oxidation when exposed to light and molecular oxygen. Pie et al(1991) reported that total COPs increased after storage and cholesterol-7 oxidized products were predominant with 7-ketocholesterol the most abundant. COPs have been detected in a variety of processed food products, including powdered milk, grated cheeses, butter and spraydried egg products. Several researchers(Higley et al., 1986; Park and Addis, 1987) have been detected COPs in raw, cooked, and processed meats. Pie et al(1991) also found that COPs increased significantly on cooking of meats and during subsequent refrigerated storage. The levels of total COPs in aerobically packaged cooked 
Table 2. Effect of cooking and packaging methods on the total cholesterol oxide products of turkey thigh meat patties during storage

\begin{tabular}{|c|c|c|c|c|c|c|c|c|}
\hline \multirow{3}{*}{ Treatments } & \multicolumn{8}{|c|}{ Storage period(days) } \\
\hline & \multicolumn{4}{|c|}{ Aerobic packaging } & \multicolumn{4}{|c|}{ Vacuum packaging } \\
\hline & 0 & 3 & 7 & SEM & 0 & 7 & 14 & SEM \\
\hline & $\ldots \ldots \cdots$ & ........... & …........ & $\cdots \mu \bar{\jmath} / \mathrm{l}$ & $\overline{\text { neat }} \cdot \ldots$. & .......... & n........ & ......... \\
\hline Oven cooking & $4.64^{\mathrm{Cc}}$ & $14.91^{\mathrm{Bb}}$ & $21.18^{\mathrm{Ca}}$ & 0.104 & $4.69^{\mathrm{Cc}}$ & $6.77^{\mathrm{Ab}}$ & $7.51^{\mathrm{Ba}}$ & 0.140 \\
\hline Pan frying & $5.20^{\mathrm{BC}}$ & $14.96^{\mathrm{Bb}}$ & $20.32^{\text {Da }}$ & 0.141 & $5.14^{\mathrm{Bc}}$ & $5.74^{\mathrm{Cb}}$ & $6.22^{\mathrm{Da}}$ & 0.101 \\
\hline Deep frying & $5.78^{\mathrm{Ac}}$ & $14.58^{\mathrm{Cb}}$ & $21.46^{\mathrm{Ba}}$ & 0.126 & $5.84^{\mathrm{Ac}}$ & $6.30^{\mathrm{Bb}}$ & $7.28^{\mathrm{Ca}}$ & 0.167 \\
\hline Boiling & $4.59^{\mathrm{Cc}}$ & $12.27^{\mathrm{Db}}$ & $19.98^{\mathrm{Ea}}$ & 0.130 & $4.55^{\mathrm{Cb}}$ & $4.70^{\mathrm{Dab}}$ & $5.64^{\mathrm{Ea}}$ & 0.199 \\
\hline Microwaving & $5.88^{\mathrm{Ac}}$ & $15.55^{\mathrm{Ab}}$ & $22.85^{\mathrm{Aa}}$ & 0.146 & $5.69^{\mathrm{Ac}}$ & $6.34^{\mathrm{Bb}}$ & $7.88^{\mathrm{Aa}}$ & 0.104 \\
\hline SEM & 0.110 & 0.140 & 0.150 & - & 0.196 & 0.163 & 0.180 & - \\
\hline
\end{tabular}

a,b,c Different letters within a row are significantly different $(\mathrm{P}<0.05)$.

${ }^{A, B, C, D, E}$ Different letters within a column are significantly different $(\mathrm{P}<0.05)$.

meat were higher than the vacuum-packaged meat. At the beginning of storage, microwave and deep fried samples had significantly $(\mathrm{P}<0.05)$ higher total COPs than those of others, but the microwaving produced highest level of total COPs in meat than other cooking methods during storage. At the end of storage, the levels of total COPs in turkey thigh meat was in decreasing order as follows: microwaving, deep frying, oven cooking, pan frying, boiling in both aerobically and vacuum packaging samples. Use microwaving for heating meat is an extremely rapid cooking method. Heating results from conversion of microwave energy to heat by friction from internal molecular rotations caused by interactions of molecules in a rapidly fluctuating electromagnetic field. Thus, microwaving method should be easily induced damage of cholesterol structure. Our results demonstrate that the rate of cholesterol oxidation in turkey is greatly accelerated during storage following cooking and appears to follow the same trend as lipid oxidation in general.

\section{Cholesterol oxidation products}

Data presented in Table 3 to 6 show that the amount of $4 \mathrm{COPs}$ (7a-hydroxycholesterol,a, $\beta$-epoxide and 7-ketocholesterol) by cooking methods and packaging methods. The levels of 4 COPs in cooked thigh meat increased with storage and the

Table 3. Effect of cooking and packaging methods on the 7a-hydroxy cholesterol of turkey thigh meat patties during storage

\begin{tabular}{|c|c|c|c|c|c|c|c|c|}
\hline \multirow{3}{*}{ Treatments } & \multicolumn{8}{|c|}{ Storage period(days) } \\
\hline & \multicolumn{4}{|c|}{ Aerobic packaging } & \multicolumn{4}{|c|}{ Vacuum packaging } \\
\hline & 0 & 3 & 7 & SEM & 0 & 7 & 14 & SEM \\
\hline & $\cdots \cdots \cdots \cdots$ & (n)......... & ............. & $\cdots \mu_{3}$ & $\overline{\text { neat }} \cdots \cdot$. & 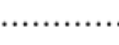 & ............. & n........ \\
\hline Oven cooking & $1.76^{\mathrm{Cc}}$ & $5.89^{\mathrm{Bb}}$ & $7.92^{\mathrm{Ba}}$ & 0.091 & $1.79^{\mathrm{Cc}}$ & $2.38^{\mathrm{Ab}}$ & $2.68^{\mathrm{ABa}}$ & 0.053 \\
\hline Pan frying & $1.70^{\mathrm{Dc}}$ & $5.75^{\mathrm{Cb}}$ & $6.94^{\mathrm{Da}}$ & 0.168 & $1.67^{\mathrm{Db}}$ & $1.73^{\mathrm{Cb}}$ & $2.01^{\mathrm{Ca}}$ & 0.120 \\
\hline Deep frying & $1.92^{\mathrm{Bc}}$ & $5.57^{\mathrm{Db}}$ & $7.53^{\mathrm{Ca}}$ & 0.114 & $1.94^{\mathrm{Bc}}$ & $2.09^{\mathrm{BCb}}$ & $2.51^{\mathrm{Ba}}$ & 0.055 \\
\hline Boiling & $1.59^{\mathrm{Ec}}$ & $4.58^{\mathrm{Eb}}$ & $7.48^{\mathrm{Ca}}$ & 0.130 & $1.62^{\mathrm{Db}}$ & $1.66^{\mathrm{Cb}}$ & $2.13^{\mathrm{Ca}}$ & 0.111 \\
\hline Microwaving & $2.14^{\mathrm{Ac}}$ & $5.98^{\mathrm{Ab}}$ & $8.27^{\mathrm{Aa}}$ & 0.137 & $2.10^{\mathrm{Ac}}$ & $2.18^{\mathrm{Bb}}$ & $2.85^{\mathrm{Aa}}$ & 0.069 \\
\hline SEM & 0.076 & 0.085 & 0.102 & - & 0.074 & 0.095 & 0.128 & - \\
\hline
\end{tabular}

a,b,c Different letters within a row are significantly different $(\mathrm{P}<0.05)$.

$A, B, C, D, E$ Different letters within a column are significantly different $(P<0.05)$. 
Table 4. Effect of cooking and packaging methods on the a-epoxide of turkey thigh meat patties during storage

\begin{tabular}{|c|c|c|c|c|c|c|c|c|}
\hline \multirow{3}{*}{ Treatments } & \multicolumn{8}{|c|}{ Storage period(days) } \\
\hline & \multicolumn{4}{|c|}{ Aerobic packaging } & \multicolumn{4}{|c|}{ Vacuum packaging } \\
\hline & 0 & 3 & 7 & SEM & 0 & 7 & 14 & SEM \\
\hline & & $\cdots \cdots \cdots$ & $\cdots \cdots \cdots$ & $\cdots \mu \mathrm{g} /$ & neat $\cdots$ & & & ...... \\
\hline Oven cooking & $0.53^{\mathrm{Bc}}$ & $1.98^{\mathrm{Bb}}$ & $2.81^{\mathrm{Ba}}$ & 0.097 & $0.55^{\mathrm{Bb}}$ & $0.63^{\mathrm{Ba}}$ & $0.60^{\mathrm{BCa}}$ & 0.084 \\
\hline Pan frying & $0.72^{\mathrm{Ac}}$ & $2.17^{\mathrm{Ab}}$ & $3.46^{\text {Aa }}$ & 0.103 & $0.69^{\mathrm{Ac}}$ & $0.91^{\mathrm{Ab}}$ & $1.08^{\mathrm{Aa}}$ & 0.106 \\
\hline Deep frying & $0.54^{\mathrm{Bc}}$ & $1.77^{\mathrm{Cb}}$ & $2.64^{\mathrm{Ca}}$ & 0.110 & $0.51^{\mathrm{BCc}}$ & $0.57^{\mathrm{Cb}}$ & $0.63^{\mathrm{BCa}}$ & 0.071 \\
\hline Boiling & $0.49^{\mathrm{Cc}}$ & $1.53^{\mathrm{Eb}}$ & $2.57^{\mathrm{Ca}}$ & 0.098 & $0.48^{\mathrm{Ca}}$ & $0.51^{\text {Da }}$ & $0.52^{\mathrm{Ca}}$ & 0.120 \\
\hline Microwaving & $0.51^{\mathrm{Cc}}$ & $1.69^{\mathrm{Db}}$ & $2.94^{\mathrm{Ba}}$ & 0.087 & $0.47^{\mathrm{Cb}}$ & $0.48^{\mathrm{Db}}$ & $0.67^{\mathrm{Ba}}$ & 0.067 \\
\hline SEM & 0.089 & 0.116 & 0.138 & - & 0.088 & 0.080 & 0.119 & - \\
\hline
\end{tabular}

a,b,c Different letters within a row are significantly different $(\mathrm{P}<0.05)$.

A,B,C,D,E Different letters within a column are significantly different $(\mathrm{P}<0.05)$.

Table 5. Effect of cooking and packaging methods on the $\beta$-epoxide of turkey thigh meat patties during storage

\begin{tabular}{|c|c|c|c|c|c|c|c|c|}
\hline \multirow{3}{*}{ Treatments } & \multicolumn{8}{|c|}{ Storage period(days) } \\
\hline & \multicolumn{4}{|c|}{ Aerobic packaging } & \multicolumn{4}{|c|}{ Vacuum packaging } \\
\hline & 0 & 3 & 7 & SEM & 0 & 7 & 14 & SEM \\
\hline & \multicolumn{8}{|c|}{ 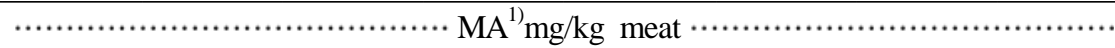 } \\
\hline Oven cooking & $0.77^{\mathrm{Bc}}$ & $3.55^{\mathrm{Ab}}$ & $4.22^{\mathrm{Ba}}$ & 0.087 & $0.74^{\mathrm{Bb}}$ & $1.32^{\mathrm{Aa}}$ & $1.37^{\mathrm{ABa}}$ & 0.148 \\
\hline Pan frying & $0.83^{\mathrm{Ac}}$ & $3.17^{\mathrm{Bb}}$ & $4.01^{\mathrm{Ca}}$ & 0.105 & $0.89^{\mathrm{Ab}}$ & $0.96^{\mathrm{Ba}}$ & $0.97^{\mathrm{Ca}}$ & 0.085 \\
\hline Deep frying & $0.82^{\mathrm{Ac}}$ & $3.03^{\mathrm{Cb}}$ & $4.54^{\mathrm{Aa}}$ & 0.099 & $0.85^{\mathrm{Ac}}$ & $0.93^{\mathrm{BCb}}$ & $1.41^{\mathrm{Aa}}$ & 0.109 \\
\hline Boiling & $0.76^{\mathrm{Bc}}$ & $2.71^{\mathrm{Db}}$ & $3.86^{\mathrm{Da}}$ & 0.111 & $0.74^{\mathrm{Bb}}$ & $0.76^{\mathrm{Cb}}$ & $1.19^{\mathrm{Ba}}$ & 0.094 \\
\hline Microwaving & $0.74^{\mathrm{BC}}$ & $3.49^{\mathrm{Ab}}$ & $4.46^{\mathrm{Aa}}$ & 0.100 & $0.70^{\mathrm{Cc}}$ & $0.99^{\mathrm{Bb}}$ & $1.43^{\mathrm{Aa}}$ & 0.080 \\
\hline SEM & 0.087 & 0.086 & 0.104 & - & 0.069 & 0.118 & 0.77 & - \\
\hline
\end{tabular}

a,b,c Different letters within a row are significantly different $(\mathrm{P}<0.05)$.

A,B,C Different letters within a column are significantly different $(\mathrm{P}<0.05)$.

Table 6. Effect of cooking and packaging methods on the 7-ketocholesterol of turkey thigh meat patties during storage

\begin{tabular}{|c|c|c|c|c|c|c|c|c|}
\hline \multirow{3}{*}{ Treatments } & \multicolumn{8}{|c|}{ Storage period(days) } \\
\hline & \multicolumn{4}{|c|}{ Aerobic packaging } & \multicolumn{4}{|c|}{ Vacuum packaging } \\
\hline & 0 & 3 & 7 & SEM & 0 & 7 & 14 & SEM \\
\hline & N.......... & tent & …..... & $\mathrm{MA}^{1)} \mathrm{n}$ & g meat . & ........... & …....... & w........ \\
\hline Oven cooking & $1.58^{\mathrm{Dc}}$ & $3.49^{\mathrm{Cb}}$ & $6.23^{\mathrm{Ca}}$ & 0.141 & $1.61^{\mathrm{Eb}}$ & $2.44^{\mathrm{Ba}}$ & $2.46^{\mathrm{Ca}}$ & 0.172 \\
\hline Pan frying & $1.95^{\mathrm{Bc}}$ & $3.87^{\mathrm{Bb}}$ & $5.91^{\mathrm{Da}}$ & 0.187 & $1.89^{\mathrm{Cb}}$ & $2.14^{\mathrm{Ca}}$ & $2.16^{\mathrm{Da}}$ & 0.087 \\
\hline Deep frying & $2.50^{\mathrm{Ac}}$ & $4.21^{\mathrm{ABb}}$ & $6.75^{\mathrm{Ba}}$ & 0.235 & $2.54^{\mathrm{Ab}}$ & $2.71^{\mathrm{Aa}}$ & $2.73^{\mathrm{Ba}}$ & 0.081 \\
\hline Boiling & $1.75^{\mathrm{Cc}}$ & $3.45^{\mathrm{Cb}}$ & $6.07^{\mathrm{Da}}$ & 0.179 & $1.71^{\mathrm{Dc}}$ & $1.77^{\mathrm{Db}}$ & $1.80^{\mathrm{Ea}}$ & 0.069 \\
\hline Microwaving & $2.49^{\mathrm{Ac}}$ & $4.39^{\mathrm{Ab}}$ & $7.18^{\mathrm{Aa}}$ & 0.258 & $2.42^{\mathrm{Bc}}$ & $2.69^{\mathrm{Ab}}$ & $2.93^{\text {Аа }}$ & 0.083 \\
\hline SEM & 0.187 & 0.271 & 0.253 & - & 0.074 & 0.098 & 0.183 & - \\
\hline
\end{tabular}

$\overline{a, b, c}$ Different letters within a row are significantly different $(\mathrm{P}<0.05)$.

A,B,C,D,E Different letters within a column are significantly different $(\mathrm{P}<0.05)$. 
increase was linear with storage time. Smith et al (1981) postulated that the intermolecular freeradical processes, involving hydrogen extraction from cholesterol by peroxy or oxy radicals of polyunsaturated fatty acids, may promote cholesterol oxidation. It is conceivable, therefore, that cholesterol oxidation should proceed in a way analogous to lipid oxidation. The levels of these $7 a-$ hydroxycholesterol and 7-ketocholesterol were higher than $\beta$ and a-epoxide and the change of $7 a-$ hydroxycholesterol and 7-ketocholesterol were in similar trend as TBARS and total COPs. At the end of storage, microwaving was significantly $(\mathrm{P}<0.05)$ the higher in $7 \mathrm{a}$-hydroxycholesterol, closely followed by the oven cooking, also, 7ketocholesterol in microwaving was significantly $(\mathrm{P}<0.05)$ the highest than other samples in both aerobically and vacuum packaging samples. Park and Addis(1986) showed that the level of 7ketocholesterol increased linearly with heating time but not with temperature in heated fats. They found that the formation of 7-ketocholesterol was nearly linear with heating time, reaching about $10 \%$ of the initial cholesterol content for $376 \mathrm{hr}$ heating at $155^{\circ} \mathrm{C}$ ark and Addis, 1985). They also suggested that cholesterol was oxidized to isomeric 7a-hydroxycholesterols, 7-ketocholesterol and epimeric epoxides in tallow heated at $155^{\circ} \mathrm{C}$ or 376 hr. 7-ketocholesterol was produced without formation of epimeric 7-hydroxycholesteol as a decomposition product of 7-hydroperoxides because 7-hydroxycholesterol was readily dehydrated in the absence of water at elevated temperatures, such as $155^{\circ} \mathrm{C}$ At the end of storage, deep frying has been shown to significantly the highest $(\mathrm{P}<0.05)$ than other cooking methods in $\mathrm{a}$ epoxide and the levels of $\beta$-epoxide in pan frying was significantly the highest $(\mathrm{P}<0.05)$ that of other samples in both aerobically and vacuum packaging samples. Paniangvait et al(1995) reported that the most predominant oxidized cholesterol detected was 7-ketocholesterol, as well as $5 \beta$-epoxycholesterol and 5a-epoxycholesterol.
Rethwill et al(1981) reported that the cholesterol7 COPs and $a$-and $\beta$-epoxide were noted at 3 and 8 days (confirmed by GC-MS), whereas TBARS were detected at 0 days and increased thereafter. 7-keto was the predominant COP formed, with $7 a, 7 \beta$, and the epoxides following in decreasing order. Allen and Foegeding(1981) reported that turkey developed higher of both COPs and TBARS than beef and has higher levels of polyunsaturated membrane lipids. In this study, we found that the amount of 4 kinds of COPs(7a-hydroxycholesterol, a, $\beta$-epoxide and 7-ketocholesterol) were little different following the cooking methods, respectively. Especially, pan frying methods increased the amount of a-epoxide, and 7a-hydroxycholesterol, $\beta$-epoxide and 7ketocholesterol increased by microwaving methods.

\section{CONCLUSION}

Conventional methods of thermal processing involve heat transfer by conduction, convection, and/or radiation. These difference of procedures should be influence meat qualities. The results indicated that the progress of cholesterol oxidation in cooked meat was similar to that of lipid oxidation, and the formation of lipid and cholesterol oxidation products in cooked meat was closely related to cooking methods, storage time, and packaging methods. The level of TBARS in oven cooking method was lower than other cooking methods, and COPs level was lowest in boiling method during storage. Especially, microwaving produced higher levels of TBARS and COPs in turkey than those of other cooking methods during storage. More research is needed to determine the effects of cooking methods and packaging methods on TBARS and COPs in meats.

\section{ABSTRACT}

Turkey thigh meats with skin were ground 
twice through a 3-mm plate and patties were prepared. Patties were cooked using 5 different methods(oven cooking, pan frying, oil deep frying, boiling, and microwaving) to an internal temperature of $85 \sim)^{\circ} \mathrm{C}$ and packaged in either oxygen permeable PVC zipperbags or oxygen impermeable PVDC bags. The samples were analyzed for thiobarbituric acid reactive substances(TBARS) and cholesterol oxidation products(COPs) after storage at $4^{\circ} \mathrm{C}$ The TBARS of cooked meat increased during the storage regardless of cooking methods, vacuum packaged thigh meat produced less TBARS and COPs than the aerobically packaged samples. At the beginning of storage, aerobically packaged meat cooked by boiling method produced higher TBARS than that of others. However, the TBARS of microwaved meat with vacuum packaging increased rapidly after 3 days of storage at $4^{\circ} \mathrm{C}$ The amount of total COPs in cooked thigh meat increased linearly with storage time. The level of total COPs in aerobically packaged cooked meat was higher than the vacuum-packaged meat. Microwave produced higher level of total COPs in meat than other cooking methods during storage.

(Key words : Turkey, TBARS, Cholesterol oxidation products, Cooking method, Packaging methods)

\section{REFERENCES}

1. Paniangvait, P., King, A. J., Jones, A. D. and German, B. G. 1995. Cholesterol oxides in foods of animal origin. J. Food Sci. 60:1159-1174.

2. Addis, P. B. 1986. Occurrence of lipid oxidation products in foods. Food Chem. Toxico. 24:1021-1030.

3. Lund, E. and Bjorkhem, I. 1994. Down-regulation of hepatic HMG-CoA reductase in mice by dietary cholesterol: importance of the 5 double bond and evidence that oxidation at C-3, C-5, C- 6 or C-7 is not involved. Biochemistry 33:291-297.

4. Peng, S. K., Taylor, C. B., Hill, J. C. and Morin, R. J. 1985. Cholesterol oxidation derivatives and arterial endothelial damage. Atherosclerosis 54: 121-133.

5. Hennig, B. and Boissonneault, G. A. 1987. Cholestan-3, 5, 6-triol decrease barrier function of cultured endothelial cell monolayers. Atherosclerosis 68:255-
261.

6. Smith, L. L. 1987. Cholesterol autoxidation 19811986. Chemistry and Physics of Lipids 44:87-125.

7. Kumar, N. and Singhal, O. P. 1992. Effect of processing conditions on the oxidation of cholesterol in ghee. J. Sci. Food Agric. 58:267-273.

8. Buege, J. A. and Aust, S. D. 1978. Microsomal lipid peroxidation. Methods Enzymol. 52:302-310.

9. Ahn, D, U., Lee, J. I., Jo, C. and Sell, J. L. 1999. Analysis of cholesterol oxides in egg yolk and turkey meat. Poultry Sci. 78:1060-1064.

10. Folch, J. M., Lees, M. and Stanley, G. H. S. 1957. A simple method for the isolation and purification of total lipids from animal tissues. J. Bio. Chem. 226:497.

11. SAS. 1996. SAS/STAT Software for PC. Releasw 6.11, SAS Institute, Cary, Nc, USA.

12. Kesava R, V., Kowale, B. N., Babu, N. P. and Bisht, G. S. 1996. Effect of cooking and storage on lipid oxidation and development of cholesterol oxidation products in water buffalo meat. Meat Sci. 43:179-185.

13. Monahan, F. J., Gray, J. I., Booren, A. M., Miller, E. R., Buckley, D. J., Morrissey, P. A. and Gomma, E. A. 1992. Influence of dietary treatment on lipid and cholesterol oxidation in pork. J. Agric. Food Chem. 40:1310-1315.

14. Allen, C. E. and Foegeding, E. A. 1981. Some lipid characteristics and interactions in muscle foodsA review. Food Technol. 35:253-256.

15. Apte, S. and Morrissey, P. A. 1987. Effect of water soluble haem and non-haem iron complexes on lipid oxidation of heated muscle systems. Food Chem. 26:213-222.

16. Pie, J. E., Spahis, K. and Seillan, C. 1991. Cholesterol oxidation in meat products during cooking and frozen storage. J. Agric. Food Chem. 39:250-254.

17. Higley, N. A., Taylor, S. L., Herian, A. M. and Lee. K. 1986. Cholesterol oxides in processed meat. Meat Sci. 16:175-188.

18. Park, S. W. and Addis, P. B. 1987. Cholesterol oxidation products in some muscle foods. J. Food Sci. 52:1500-1503.

19. Smith, L. L. 1981. Cholesterol Autoxidation; Plenum Press: New York.

20. Park, S. W. and Addis, P. B. 1986. Further investigation of oxidized cholesterol derivatives in heated fats. J. Food Sci. 51:1380-1381.

21. Park, S. W. and Addis, P. B. 1985. HPLC determination of C-7 oxidized cholesterol derivatives in foods. J. Food Sci. 50:1437-1444.

22. Rethwill, C. E., Bruin, T. K., Waibel, P. E. and Addis, P. B. 1981. Influence of dietary fat source and vitamin $\mathrm{E}$ on market stability of turkeys. Poultry Sci. 60:2466-2469.

(접수일자 : 2004. 1. 13. / 채택일자 : 2004. 3. 31.) 